Published as: Azadi, H., Houshyar, E., Zarafshani, K., Hosseininia, G. \& Witlox, F. (2012). Agricultural Outsourcing: A Two-Headed Coin? Global and Planetary Change, vol. 100(2013), 20-27.

\title{
Agricultural Outsourcing: A Two-Headed Coin?
}

\author{
Hossein Azadi $^{\mathrm{a}}$, Ehsan Houshyar ${ }^{\mathrm{b}}$, Kiumars Zarafshani ${ }^{\mathrm{c}}$, \\ Gholamhossein Hosseininia ${ }^{\mathrm{d}}$, Frank Witlox ${ }^{\mathrm{a}}$ \\ ${ }^{a}$ Department of Geography, Ghent University, Belgium. \\ ${ }^{\mathrm{b}}$ Department of Farm Machinery and Mechanization, College of Agriculture, Shahid Chamran University, Ahvaz, Iran. \\ ${ }^{\mathrm{c}}$ Department of Agricultural Extension and Rural Development, Razi University, Iran. \\ ${ }^{\mathrm{d}}$ Department of Entrepreneurship in Technology, Faculty of Entrepreneurship, Tehran University, Iran.
}

\section{Abstract}

Since two decades ago, when China's economic strength has made this most populated country as a leading global agricultural outsourcer, there have increasingly been hot debates on whether such outsourcing is destructive or constructive, especially for host countries. Some critics pessimistically call it 'land grabs' or 'neo-colonialism' that should be prevented while others optimistically appreciate it as a development opportunity that should be promoted. The first group interprets the outsourcing as a win-loss process while the second considers it as a win-win deal. This study tries to show the possible gains and losses of both outsourcers and host countries. Accordingly, this paper introduces four different situations; i.e. loss-loss; win-loss; loss-win; and win-win. The first situation is understood as a 'red-deal' which should urgently be stopped. The second and third situations are called 'yellow-deal' which should be adjusted to come up with the last situation which we call 'green-deal' that addresses the benefits of both outsourcers and outsourcees. The paper concludes that in order to understand the main impacts

\footnotetext{
${ }^{1}$ Corresponding author. Email: hossein.azadi@ugent.be, Tel. +32 (0)9 26446 95. Fax +32 (0)9 2644985.
} 
28 of such deals, we still need to create more evidence for each situation in the framework of a 29 series of risk assessment studies on the bases of both "country-case" and "crop-case".

30 Keywords: land deal, land grab, neo-colonialism, agricultural investment, agricultural 31 development. 


\section{Introduction}

33 A secure and sustainable food production system is needed for surviving human being societies.

34 The world is making only slow progress in reducing food insecurity, according to the Global

35 Hunger Index $(\mathrm{GHI})^{2}$ (Ackello-Ogutu, 2011). Some regions-in particular South and Southeast

36 Asia, the Near East and North Africa, and Latin America and the Caribbean-have made

37 significant headway in combating hunger and malnutrition since 1990, but in South Asia and

38 Sub-Saharan Africa, the GHI still remains high (Grebmer et al., 2008). While one billion people currently suffer from hunger (UN, 2009), the Food and Agriculture Organization (FAO, 2009a)

40 of the United Nations estimates that by 2050, the world's population will exceed 9 billion, most

41 of which will be inhabitants of the developing world.

42 At the same time, the majority of the world's remaining cultivatable land lies in developing 43 countries (Cotula et al., 2009). Many large land areas in the developing world are in fact

44 cultivated by indigenous communities, but return very low yields. This limits the capacity of the 45 developing world to meet the world's demands without outside investment (Hallam, 2009). Most of Sub-Saharan African nations suffer from food insecurity. Among all, according to the latest

47 GHI scores (in 2011), three countries ${ }^{3}$ stay at "extremely alarming" and 13 countries ${ }^{4}$ at 48 "alarming" mode (Wünsche, 2011). Consequently, it seems that they need a great help to 49 produce enough food for their own and also other countries with insufficient cultivable land. Yet, 50 the food and fuel scarcities push some countries, especially capital-rich and natural resources-

51 poor nations like China, South Korea, Japan, Saudi Arabia and Kuwait (STWR, 2012) to buy or

52 lease huge quantities of foreign lands mainly for the production of food and biofuels for 53 domestic consumption (Haralambous, 2009).

\footnotetext{
${ }^{2}$ The GHI is a multidimensional statistical tool and measures progress and failures in the global fight against hunger.

${ }^{3}$ Democratic Republic of Congo, Eritrea and Chad.

${ }^{4}$ Ethiopia, Central African Republic, Comoros, Sierra Leone, Madagascar, Mozambique, Zambia, Angola, Tanzania, Malawi, Sudan, Niger, Liberia.
} 
Since about 95 percent of Asia's croplands have already been used, Africa and Latin America

55 are seen as the most likely places where foreign investors will seek arable land (Kersting, 2011).

56 The cheap and abundant farmlands in developing nations, particularly in Africa, drive capital

57 rich nations to outsource their food productions (Cotula et al., 2009). Among agricultural outsourcing (AO) scramblers, some of the most populated countries; i.e. China and India, have

59 put serious attempts to drive global AO due to domestic shortages in land, energy and natural 60 resources (Friis and Reenberg, 2010). Yet, the scarcity of land and sprawling overpopulation in

61 those countries have led to political backlashes that prompted the central government to turn its 62 attention to Africa at the beginning of this decade to fill its people's rice bowl (Horta, 2009).

63 Since the 1990s, in order to accommodate the food and energy growing demand, China, the most 64 populated country in the world, has come into this picture as the main feature. In Latin America, 65 overall Chinese direct investments have been small but on rise. Currently, China's interest in this 66 region has focused on oil and metals, not agriculture (Davies, 2009). By 2011, 26 Chinese 67 companies have been actively in negotiation with Latin American and African countries 68 especially Argentina, Brazil, Mozambique, Nigeria, Angola, Malawi, Sudan, Ethiopia, 69 Madagascar and Zimbabwe to invest on agriculture, food, forestry, fishery and biofuels 70 (Saturnino et al., 2011; Afripol, 2010; Cobo et al., 2011).

71 Much of the AO is taking place in developing countries with weaker governance and less 72 developed civil societies (Grindle, 2002). Among others, the most AO is taking place in Africa. 73 Although foreign nationalities have been engaged in agriculture in this continent for many years, 74 the scale of such deals has increased significantly in recent years. Consequently, the contentious 75 issue of 'land grabbing' has become the subject of numerous media reports since the global food 76 crisis worsened in 2008 (FIAN, 2012). The latest wave of land grabbing began towards the end 
of 2008 when the global food crisis generated a serious concern over supplies in countries that

78 consume more food than what they produce (STWR, 2012).

79 Across Africa, governments are already leasing large areas of land that are traditionally used 80 by small-scale farmers to transnational companies for industrial agriculture or for planting trees 81 as carbon sinks so as to gain carbon credits. Pearce (2011) asks whether such a lease will

82 accelerate if the soil itself becomes a carbon commodity. According to him, the high costs of 83 employing scientists, consultants, and practitioners to monitor the carbon uptake of farm soils 84 will make it unfeasible for poor farmers to pocket any income from the sale of the carbon 85 absorbed by their soils. He believes that only rich farmers are able to lessen these transactions 86 costs significantly to profit from the carbon markets. Consequently, a new phase of land 87 grabbing — called "soil grabbing" is taking place in this continent.

88 Another essential issue is that the desire to use water resources is embedded in many land deals (Woodhouse and Ganho 2011; Skinner and Cotula, 2011). In many cases water itself is the 90 target of deals, not only for agricultural purposes but also for other purposes like mining which 91 could result in "water grabbing” (Mehta et al., 2012).

92 Concurring with the liberalisation of trade, competition for $\mathrm{AO}$ is more and more played out 93 directly between local land users, national economic elites, and transnational investors (Oxfam, 94 2009). As a result, land acquisitions are on the increase in Africa and other continents, raising the 95 risk or opportunity that poor people will be evicted or lose access to land, water, and other 96 resources, if not made properly (FAO, 2009b), or gain some benefits to promote their socio97 economic and ecological services and facilities. Correspondingly, some believe that AO has generated some envisage economic opportunities for local communities while others see it as a 99 serious threat to the livelihoods of local poor people (Friis and Reenberg, 2010; Madebo, 2011; 100 Smaller and Mann, 2009; Ezra, 2010; Mihretie, 2010; Smith, 2010; Grau and Aide, 2008). 
Although indicative evidence has started to emerge, there is yet very little systematic monitoring of these trends, research into the impacts, or exploration of the opportunities that may be created for rural development. These trends pose both a threat and an opportunity to the rural 104 poor, who are increasingly losing their land rights and the future food production security. 105 Particularly, dispossession is likely to occur where their land tenure rights are weak and unrecognized. Most at risk are groups such as women, pastoralists, indigenous people and others 107 dependent on customary and common-pool resource rights that are insecure and undocumented 108 (Quan, 2006). The vulnerability of these groups is often compounded by corruption that can 109 accompany large-scale land transfers. There is already evidence of the displacement of poor resource-users by agro-fuels production, while others may lose access to resources, such as

111 rangelands and forests, which may constitute an important safety net and livelihood source for 112 marginalized groups. However, where poor people have secure land use rights, these trends may 113 actually offer opportunities for development.

114 Hence, the question surfaces whether AO has an entirely negative impact as critics posit, or 115 whether it might also carry some potential benefits. Furthermore, there remain some other crucial 116 questions as follows: what are the main subsequent of global AO? Are the consequences 117 destructive or constructive and for whom? Will the AO be a win-win or a win-loss deal? And 118 what are the main gains and losses of such deals?

\section{A two-headed coin: win or loss?}

121 AO can be considered as a two-headed coin since it can lead to win and/or loss. It is clear that 122 investors and investees both expect to win the most and loss the least. Undoubtedly, the investors 123 come to developing countries to earn something, i.e. food and energy security. But the big 124 question is that what they would bring to the host (mostly poor) countries. It is essential to 
regulate the conditions that can direct AO to win for both sides of the deal. However, apparently, as a consequence of investors' power and investees' weakness, the most so far AOs have led to win for the guest and loss for the host countries. AO must reduce, and not expand, the number of hungers and communities that struggle to survive. Leaseholders might push the host governments for better tax situations for farmers, while host countries could insist on the local hiring. Some empirical studies of the past few years clearly indicated that foreign investment companies are profiting from "land grab", and AO in developing countries has failed to deliver its promise of jobs, infrastructure, schools, and health facilities (Madebo, 2011). Large land deals also carry big risks. Local people can end up with losing the land, water and other resources that have supported their livelihoods for generations, while the jobs created in return may be few, short-lived and low-paid (Cotula, 2011). Cotula (2012) believes that the global "land grab" reflects profound economic and social transformations in agriculture and if it sustained over the next few years, will have profound implications for the future of world agriculture. Yet, some organisations think this could be a chance for poor countries to trade land and labour for the technology and investment vital for developing their own food and energy production systems and should not generally be condemned (Mackenzie, 2008).

One of the main opportunities for the host countries is that the investors need to import a portion of their own technologies to produce crop and construct the needed or promised infrastructures to reach a successful production or goods transportation. For instance, they import farm machines, equipments and irrigation systems (Grain, 2009). Also, they would set up warehouses and buildings to repair and maintain farm machines and irrigation systems. Additionally, proper roads and railways must be constructed to export products and import all needed things like farm machines and equipments, irrigation systems, chemicals, fertilizers and seeds (UN, 2007; Meentzen, 2010; Ullenberg, 2009). As seen, constructing some infrastructures 
can facilitate the host countries to approach development. However, the contribution of local people is essential to learn how to build such infrastructures. If investors fairly allow local people to participate in establishing infrastructures and train them, at least a portion of successful technology transfer becomes guaranteed (Maskus, 2004). Such a situation can surely be expected as a development opportunity for host countries and considered as a win-win deal.

Nations must understand the motivations of foreign investors in farmland acquisition. Most investors are leasing land in Africa because they suffer already from some irreversibly depleted natural resource stocks in their home nations (Robertson and Pinstrup-Andersen, 2010). If the deals are properly regulated, genuine agricultural investments by operators with a strong track record can create opportunities for recipient countries and local people, bringing capital, knowhow, jobs, market access and infrastructure development (Kugelman and Levenstein, 2009). To make a properly regulated deal, political, socio-economic and environmental aspects with respect to local conditions especially in the host countries should be considered. Otherwise, there may be severe environmental, economic, political and social losses for investees. Thus, it is very crucial to realize which deals can be seen as "land grabbing" and in what conditions it can cruelly be "land grabbing" or friendly be a "development opportunity". Accordingly, this paper discusses that AO could be a "two-headed coin" and has some win and losses for both sides (investor and investee). Therefore, one can expected four different statuses for the host and guest countries as shown in Fig. 1. The statuses are discussed in the following.

[insert Fig. 1]

\subsection{Loss-Loss: red deals (destructive; should be stopped)}

We start with the worst situation where transnational land deals are destructive for both outsourcers and outsourcees. We call such loss-loss deals as "red deals" because the deals cause 
173 some losses to both investors and investees. In such a situation, both the land dealers mostly loss 174 and hardly gain any benefits. The potential losses for outsourcers are capital, time, and some 175 possible social conflicts with the local people and political conflicts at the international level 176 (Songwe and Deininger, 2009). The main losses of the outsourcee could be more severe than the 177 outsourcer. These losses could be seen from political, socio-economic and environmental points 178 of view. Internal conflicts and riots against the governmental policies might be the main political 179 losses in the host countries (Safransky and Wolford, 2011).

180 The lack of enough job opportunities, no public self-confidence, no suitable land tenure 181 system and non-secure food production system are the main socio-economic losses in such deals 182 (Behrman et al., 2011). Unsustainable land tenure system would cause many social conflicts not 183 only between the outsourcers and outsourcees, but also within the local community (FAO, 2004). 184 Consequently, an unsustainable food production system (Azadi et al., 2011a) is expected. Hence, 185 "red deals" are destructive and should be stopped. In other words, such deals can end to an 186 unsustainable agricultural system and therefore unsustainable development as shown in red color 187 as a warning color to stop the deals. The unsustainable situation means that the outsourcees' 188 agricultural system will be damaged by different drivers mainly caused by the outsourcer. 189 Destroyed potential agricultural farms and depleted water resources may stop the outsourcees' 190 food production system (DEXIA, 2010). Indeed, environmental losses can affect the host 191 countries in such a way that they can hardly live and survive (Nayak, 2004).

193 2.2. Win-Loss: yellow deals (neo-colonialism; should be adjusted)

194 We call win-loss deals "yellow deals" since these deals may bring some benefits (e.g. 195 infrastructures, schools or food and biofuel) only for one side. In win-loss deals the investors 
gain and the investees loss. Therefore, these "yellow" deals should be adjusted to reach a winwin situation.

Many commentators warn that investors will grow food in host countries with their own labours and technologies, and then ship the food back to the guest countries for their local consumption (Montenegro, 2009). If this habit of selling fertile land continues, there will soon be no fertile land left for the coming generations. Instead, the future generation will become serfs in the land of their own country. Such a policy should be adjusted in a way that can bring some benefits for local people (Ali, 2009). Otherwise, purchasing or long-run leasing farmland in a region with fertile soils and potential water resources is unsustainable and can easily lead to a great loss for the host countries. The commentators worry also that the investors will not bring jobs to investees, and will instead carry land deals to the firms and labourers of guest countries. Given this stark assessment, many see AO nothing more than a grab for cheap, underutilized land. Some (e.g. Jacques Diouf, director of the FAO) have gone so far as to specifically label this type of aggressive land-leasing as “neo-colonialism” (Rubinstein, 2009).

In win-loss deals, the same problems as the loss-loss deals would happen for the host countries. In this case, the outsourcer's investments in the outsourcee would cause some gains for the former and mainly losses for the latter. However, it seems that there is no absolute win for investors in such situations. For instance, a guest country may gain proper food and biofuel, but miss its political position in the host country. To raise a secure food production system, what is worrisome is that the global food production and distribution channel is in the hands of a few international agribusiness companies with ties to hedge funds. Additionally, the motivation and role of big agricultural outsourcer like China, South Korea, Saudi Arabia, Qatar, and United Arab Emirates should be evaluated more in details. Also, the consequences of their foreign land deals especially in main poor AO recipients, i.e. Sudan, Ethiopia, Madagascar and Mozambique 
220

221

222

223

224

225

226

227

228

229

230

231

232

233

234

235

236

237

238

239

240

241

242

243

(Hong, 2011) should be analysed more sensitively. For instance, the role of China, as the largest global land dealer, needs a more subtle analysis (Smith, 2009) to avoid win-loss deals especially in the South countries. Without such measures, however, developing countries simply risk to sell out their resources (Hartwich, 2009). Because if China's ambitious plans are not carried out with proper regulations for the environment and its impact on Africa's agricultural land, the continent may one day find itself in a similar predicament to the one confronting China today (Horta, 2009).

Amongst the host poor countries, Ethiopia is one of the most reckless countries that denies ownership of land to its own poor peasants (Azadi et al., 2011b) and sells the nation's top level fertile land to foreign investors. In this country, between 2004 and early 2009, farmlands were bought or leased on an immense scale (1.48 million acres). The country has further approved 815 foreign-financed agricultural projects since 2007 and land is being leased for approximately \$1 per year for 2.5 acres (Globalvoices, 2011). Another deal between the Ethiopian government and the South Korean company Daewoo allowed the firm to export as much as it likes to produce (Ezra, 2010). Ethiopia is in the midst of a severe food crisis and is heavily dependent on food aid to feed its people (Hobbelink, 2011). Such aforementioned deals with low income could exacerbate the poverty in the country and may be ended to much internal riots against local governments and foreign investors. Another report reveals that Daewoo Logistics was in negotiation with Malagasy's government to lease $1.3 \mathrm{~m}$ hectares of farmland - about half of all arable land in Madagascar - in 4 coastal regions for 99 years. It planned to produce 500,000 tons of palm oil in the eastern parts of the country and 4,000,000 tons of corn in the western parts and export most of the production back to South Korea (Hong, 2011). Such long-run large-scale land deals may cause the country to a disastrous future seeking for food especially if the investors export much of their productions and make no job and income for indigenous people. 
245 Ethiopia, explained how companies have been making quite indecent proposals to his 246 government to grab their lands for 10 years, for free and no taxes. Ethiopians, in return, earn

247 nothing else than some of the foods they produced but sold by guests. It seems that such deals 248 resulted in a new version of the $19^{\text {th }}$ century scramble for Africa (Rudi et al., 2012), a real neo249 colonialism.

250 All these are evident examples of such win-loss deals which we called yellow deals. Most 251 African economies are heavily reliant on agriculture and natural resources for a significant share 252 of Gross Domestic Production (GDP), national food needs, employment and export revenue 253 (Mutangadura, 2007; Rudi et al., 2012). Since, most of the host countries are African with a lot 254 of poor and hungry people, such win-loss deals are considered as the "land grabs" (Saturnino et 255 al., 2010) and have sparked accusations of neo-colonialism and fears that the practice could 256 exacerbate the poverty and lead Africans to a catastrophic future. According to the World Bank, 257 the global land grab is very real and moving along faster and further than what was previously 258 understood. Therefore, some benevolent regulations are expected to modify "yellow deals" in 259 such a way that can come up with win-win deals.

\subsection{Loss-Win: yellow deals (aid; should be adjusted)}

262 In loss-win deals the investors would gain nothing, or at least, not as much as they were 263 expecting while the investees receive infrastructures, new technologies, health centers and so 264 forth. Similar to win-loss deals, we call loss-win deals "yellow deals" since they may bring some 265 infrastructures and services for the host countries but no significant wins for the investors. This 266 status would happen in wide deals with establishing a lot of infrastructures (e.g.) like the "Varun 267 Agriculture Sarl" (VAS) contract in Madagascar. VAS leased or purchased 232,000 ha to grow 
269 exchange for the rights to the land, VAS undertook to establish health centers, schools, training

270 sites, road infrastructure, drinking water, houses and equipment for security guards in the region

271 where it is necessary for the project (TopManda, 2009). This deal is based on a contract farming

272 and hopefully will end to a win-win deal. In addition to obtaining infrastructures, a loss-win deal

273 would be a great opportunity for the local people to grab and absorb the imported technologies

274 from guest countries, especially if they contribute to produce crops or set up the infrastructures.

275 Actually, providing these situations help host (poor) nations produce and establish crops and

276 infrastructures. Therefore, in spite of the investors' losses, loss-win deals would bring some

277 noticeable opportunity to the investees. Although some governmental or private investors help

278 the poor nations to get developed, most of investors would not simply spoil their capitals or 279 spend them for nothing else than an aid. Consequently, loss-win deals can be cited as "aid" to 280 host countries.

282 2.4. Win-Win: green deals (constructive; should be promoted)

283 Despite the potential pitfalls, outsourcers' investments in outsourcees might have the potential to 284 significantly promote the agricultural sector of host countries. Unprecedented improvements to 285 infrastructure, increases in education and available technology, and an influx of invested capital 286 could bring sustainable solutions to investees' food troubles (Haralambous, 2009). For instance, 287 while China may primarily be motivated by its need to meet its rising food demand, the 288 modernization of the African agricultural sector is also likely to benefit the people of that 289 continent. For example, Ugandan government thanked China for its support in developing the 
country's agricultural industry (UGPulse, 2007) ${ }^{5}$. In Kampala, China is funding projects to

291 increase awareness of sustainable fishing practices in an effort to ease the over fishing of Lake

292 Victoria - the source of much of the fish-heavy diet in Uganda (Rubinstein, 2009). After serious

293 food shortages last year that degenerated into violent riots, the Senegalese government was eager

294 to attract Chinese investments (Horta, 2009). Nigerian economist; Jonas Chianu looks at China's

295 agricultural strategy in Africa as an unprecedented investment in agricultural sectors of many

296 nations. He believes that trading land rights for overall development is a way forward. Without

297 the Chinese, under-utilized farmland would remain unproductive, benefiting no one. Chianu

298 stated that instead of allowing the resources to lie unexploited, it is better to embark on lease

299 arrangements (Namibian, 2012). China is also promised to share information with the Latin

300 American farmers, as it has done in Africa, to improve crop productivity. China has therefore

301 promised to invest billions of dollars in infrastructure in the region, which would improve the

302 flow of goods to international markets (Ewing, 2009). Accordingly, we called win-win deals

303 "green deals" because they end to gain for both sides and would hopefully result in sustainable

304 food production systems though all this must be tracked by a continuous risk assessment study.

305 Such systems would be much constructive and eradicate hunger and poverty in both host and

306 guest countries, feeding current and the next generations. A sustainable agri-rural development is

307 therefore expected especially for host (poor) countries as a consequence of green deals. "Green

308 grabbing" is another term which refers to the appropriation of land and resources for

309 environmental ends. Appropriation' implies the transfer of ownership, use rights and control over

310 resources that were once publicly or privately owned from the poor into the hands of the

311 powerful (Fairhead et al., 2012). Seemingly, land appropriation interacts with other forms of

312 appropriation, financial speculation in commodities, and entry barriers to erode smallholder

${ }^{5}$ http://www.ugpulse.com/uganda-news/government/china-offers-30million-us-dollars-to-uganda/4313.aspx 
313 livelihoods (Amanor, 2012). "Green grabbing" could be a "red", "yellow" or "green" deal based 314 on who wins and who losses.

315 As discussed earlier, the investors need to built some infrastructures such as roads and 316 railways and import some technologies like farm machines and equipments. To get a real win317 win deal and sustainable development, investors should allow local people to contribute and 318 learn how to construct the infrastructures, or how to repair and maintain farm machines and 319 irrigation systems. Nonetheless, the inherent talent and ability of the local people are essential to 320 absorb the imported technologies, even if the investors banned them to collaborate.

\section{$322 \quad 3$. What should be studied?}

323 Land deals have some small or big aftermaths with regard to political, socio-economic and 324 environmental issues especially for host countries, and remarkably in the large-scale, long-run 325 deals. It seems that it is a governmental responsibility to analyze the deals' consequences and 326 make a wise decision about dis/agreement. A series of risk assessment studies is needed to 327 evaluate all political, socio-economic and environmental situations that end to "red", "yellow" 328 and "green" deals. Although the FAO suggests some measures to be taken in order to regulate 329 land acquisitions and guarantee a minimum benefit for investees to reconcile the investors' 330 interests (Godoy, 2009), blindly signing the deal would result in red and yellow deals that bring 331 irreversible losses and disastrous future, mostly for host countries. The main essential aspects 332 from political, socio-economic and environmental points of view to be considered in each deal 333 are discussed in the following sections. 


\subsection{Political aspects}

337 The main question here could be addressed to whether AO can influence political relations of 338 guests and host countries. In other words, could AO ameliorate or deteriorate the dealers' 339 political relationships? To what extent it could be destructive or constructive? How will be the 340 status of land tenure systems? Could the dealers already extend their cooperation in other sectors 341 successfully? Or is it mostly destructive so that the dealers would not promote their cooperation?

342 Which dealer will gain more bargaining power?

343 It is essential to find the accurate answer for each question to establish a successful "green 344 deal". However, for political aspects, two layers of dis/satisfaction can be expected: one at the 345 governmental and the other at the public level.

346 Although countries that lease or sell their land often suffer from weak governing institutions 347 (Simon, 2009), it seems that some stronger governments inspect the performance of investors 348 carefully. Consequently, investors and investees can protect their leases with the investor 349 protection provisions of international trade pacts $^{6}$. Since securing land rights is central to 350 ensuring equitable agricultural development (Rota, 2009), farmers' land tenure rights must 351 precede land deal negotiations. Furthermore, rights to land are the basis for social relationships 352 and cultural values, and a source of prestige and often power and political status (FAO, 2002).

353 Purchasing or long-term leasing of fertile land would result in dissatisfactions and even 354 internal riots in host countries. The deals frequently set one group against another in host 355 countries and the question is how those conflicts get resolved ${ }^{7}$. For instance, Peru's government 356 used deadly force against indigenous people that protested petrochemical and logging interests' 357 access to traditional land (Simon, 2009). In Madagascar, the South Korea's Daewoo wanted to

\footnotetext{
${ }^{6}$ www.foodandwaterwatch.org

${ }^{7}$ http://www.economist.com/node/13692889
} 
secure 1.3 million hectares to grow corn, but the deal collapsed for political reasons (Smith,

359 2009). Such actions show that purchasing or long-term investments on a desired region are not

360 reasonable, because in cases like riots or even revolutions investors' rights cannot be guaranteed.

361 Therefore, as the aftermath of such deals the "red" end, from political point of view, is expected.

362 However, respecting customary rights, sharing benefits among locals and increasing

363 transparency (current deals are shrouded in secrecy) would terminate the conflicts.

364 At last but not least, since investors purchase or lease the potential lands (e.g., those with

365 irrigation potential or closer to markets) (Von Braun and Meinzen-Dick, 2009), from a

366 pessimistically point of view, selling fertile land continuously may lead to a serious threat to host

367 countries' independency and territorial integrity.

\subsection{Socio-economic aspects}

370 The main social issues here are food security, displacement of indigenous people, loss of income 371 opportunities, social inequities, and conflicts. The main concern here would be the current and 372 future situation of small-scale farmers. Are their conditions better than before? Or they are more 373 deprived? Do they have more bargaining power? Do they gain more job opportunities? Or they 374 are more marginalised as a simple worker? How about their social welfare? To what extent the 375 guest would offer and construct infrastructure/facilities for the host communities? Do local 376 people have now an easier access to more and better foods? Are the foods cheaper than before?

377 Do the local people produce and earn more than before? Do the local people have more access to 378 market? How about the land price fluctuation in the host countries? How about the governance? 379 What would be the position of the governance?

380 Poor countries' central governments usually have neither the capacity nor the local knowledge to 381 implement a just, large-scale national land registration system (Clover and Eriksen, 2009). With 
such a high proportion of land being unregistered, the risks of dispossession for the poor majority

383 from a major land-grab are very high (Toulmin, 2008a). Most cultivable land is already used or

384 claimed by local farmers, herders and gatherers with no formal documentation (Toulmin, 2008b).

385 For instance, up to 90 percent of rural land is under customary tenure in Africa (Gerlach and Liu,

386 2010). It is expected that local poor and vulnerable people displacement is the main negative

387 social impacts of $\mathrm{AO}$ in this continent. Gender is critical to understanding the impact of land

388 deals because 'men and women have different social roles, rights, and opportunities and will be

389 differentially affected by any major change in tenure, especially land transfers to foreign

390 investors (White and White, 2012). The challenge is that these people have little access to the

391 law and are excluded from formal land rights (Rudi et al., 2012). This problem would therefore

392 worsen land tenure conflicts between the investors and local people. The investors would grab a

393 part of the political, social and economic governance besides the land grabbing. From the

394 governance point of view, land grabs violate the position of governance at all levels of human

395 life: accountability, predictability, adherence to the rule of law, and human rights (Simo, 2011).

396 It seems that to avoid this, the investors' activities should be well organized by the governments

397 of host countries (Daniel, 2012).

398 The extent of the technology that must be or can be transferred from guest to host countries is

399 essential since there would be some socio-economic, political and environmental side effects.

400 For a green deal, indigenous people must contribute to the process of crop production and

401 constructing infrastructures. The contribution of the local people is essential since by creation

402 more jobs and income for men and women, it helps them absorb and accept needed technologies

403 more eagerly (Behrman et al., 2011). Consequently, such conditions ameliorate people's self-

404 confidence for successful food productions after the departure of investors. Consistently, it 405 would be a green deal from social and political points of view. Also, the local people's 
contribution results in job creation and is important from both the social and economic aspects (Saturnino et al., 2010). However, the uneven development can be expected in different regions of the host countries, between where the investors' technologies are imported and where are not. Such an uneven development may cause a socio-economic problem, mainly increasing gap between the rich and the poor.

Some case studies observed that land deals projects are labour intensive during the initial phase but become increasingly mechanized later on, thus reducing future income opportunities (Gerlach and Liu, 2010). Nonetheless, it is expected that as a consequence of green deals, the host countries will be gained a more sustainable economic growth. Land and agricultural production have been highlighted as critical for economic growth and poverty reduction (Clover and Eriksen, 2009). As a consequence of technology transfer, infrastructures construction and capital flow from investors to investees, agricultural output and productivity will be increased. Additionally, employment creation upgrades domestic production (Hallam, 2009) and boosts the economic growth.

As discussed earlier, a worrisome issue is that all the produced foods in host countries may be shipped to guest countries for their local consumptions. In this situation, poor people do not have access to enough food to survive and it may therefore exacerbate the poverty. To avoid such insecure situations where job creation and food security are threatened, investors should contribute to the local people's food security as well.

\subsection{Environmental aspects}

Environmental impacts are also one of the main issues that need to be addressed when assessing the consequences of AO. Many of the land buyers, especially from arid and import dependent countries, are essentially seeking access to water as much as they buy land (Woodhouse and 
430 Ganho, 2011) which is already referred to as "water grabbing". The problematic issue is that the

431 volume of needed water for large-scale agricultural projects is not explicitly mentioned in many

432 land deal contracts (Woodhouse, 2012). Thus, there is a need to assess available and required

433 water for the specific period of each deal (Mehta et al., 2012).

434 Since most of the investors buy or lease lands to feed their own nations, seemingly, they

435 produce a few numbers of crops for several years. This may cause a significant loss in

436 biodiversity due to the introduction of monoculture (Bazuin et al., 2011). Also, most likely,

437 investors choose some types of agricultural systems to reach the higher yields especially in the

438 short-run leases. For instance, most conservation tillage systems have lower outputs than the

439 conventional ones (Coughenour and Chamala, 2000), but they are much more sustainable.

440 Capital-intensive agricultural practices, typical of the current land acquisition, use large amounts

441 of fresh water resources and depend heavily on fertilizers and pesticides (Spieldoch and Murphy

442 2009). The investors will want a quick return. They will practice an industrial model of

443 agriculture (Azadi et al., 2011c; Rudi et al., 2012) that in many parts of the world has already

444 resulted in poverty, environmental destruction and farm-chemical pollution (Nayak, 2004). In

445 this case, over use of pesticides and fertilizers can lead to soil and water contamination.

446 Although purchase or long-run lease have more political and socio-economic effects on host

447 countries, the environmental damage is more severe in short-run leases since investors may put a

448 pressure on land and water resources to reach a higher yield as much as possible (Azadi et al.,

449 2011d). Consequently, there would be nothing for local communities at the end of the contracts.

450 In fact, land and water grabs; due to investors' recklessness and lack of control from host

451 countries may lead to huge environmental problems in outsourcees. To avoid this situation, some

452 sorts of crops and rotation schedules, agricultural and irrigation systems, the quantity and quality 
453 of inputs, i.e. farm machines, fertilizers and pesticides should be clearly regulated before signing 454 the deal.

\section{Conclusion}

457 This study showed that AO can be resulted in four different statuses, i.e. loss-loss, win-loss, loss458 win, and win-win. The first and the last deals are introduced as "red" and "green" deal since they 459 result respectively in loss and gain for both the investor and investee. The two other deals are 460 called "yellow" since one side gain much and the other less. The "red deals" are destructive and 461 should be stopped because both sides gain nothing and would face unsustainable and insecure 462 food production systems. The "yellow deals" should be modified in such a way that results in a 463 "green" deal to profit both the investors and investees. To reach a beneficial "green deal", 464 political, governance, socio-economic and environmental effects of each deal should be studied. 465 Since rights to land are a basis for social relationships and cultural values, and a source of 466 prestige and often power and political status in developing countries, farmers' land tenure rights 467 must precede land deal negotiations. Furthermore, as a result of high proportion of unregistered 468 land in poor countries, the risk of dispossession through a land grab for the majority of poor is 469 very high. Indeed, only where poor people have secure land use rights, AO can actually offer a 470 platform for development. Additionally, the duration and the size of investment (Hall, 2011) are

471 critical factors that affect the future of the deals. It is also important to note that large size 472 purchasing or long-run land leasing may be understood as a win-win "green deal" for the first 473 years but due to the social dissatisfactions and probable riots, such deals may be realized 474 unsustainable and would result in a "yellow" or "red" end.

475 Unfortunately, the majority of host countries lack basic data on the size, nature, and the 476 location of land acquisitions through land registries or other public sources (Cotula et al., 2009), 
477 and that researchers needed to make multiple contacts to access even superficial and incomplete

478 information. Also, many details of land deals are still hidden (FIAN, 2012) that inhibits a series

479 of risk assessment studies to find what will happen and how will be the future of host countries.

480 A challenging issue is that the losses in host countries would be much more severe than in the

481 guests. Appropriately, the World Bank has launched some relevant studies on the basis of the

482 projects that have been reported by the media and captured by the farmlandgrab organization ${ }^{8}$,

$483 \mathrm{LDPI}^{9}, \mathrm{ICAS}^{10}$ and PLAAS ${ }^{11}$. The Bank's most significant findings, however, are about the

484 social impact assessment of these projects on local communities. Environmental impact

485 assessments are rarely addressed, and people are routinely booted off their land, without

486 consultation or compensation. For that reason, the host governments have to evaluate the

487 consequences of deals very prudently. The political, socio-economic and most essentially

488 environmental impacts of each deal must be studied continuously. The consideration of

489 environmental effects are emphasized in the fact that most environmental losses like depleted

490 and eroded water and soil resources are irreversible and could not be simply compensated.

491 Particularly, the availability and needed water for a specific deal should carefully be investigated

492 to prevent the "water grabbing" phenomenon. For all this, we still need to create more evidence

493 for each of the situations, i.e. "red", "yellow" and "green" deals by conducting more case studies

494 in different regions. Most essentially, an "authorized continuous monitoring system" is needed to

495 inspect the performance of the investors in host countries to come to a green deal. Such a system

496 should help both the host and guest countries to make a "continuous" monitoring system on the

497 consequences of the deals. Both the countries should therefore not be difficult to let third parties

\footnotetext{
${ }^{8}$ farmlandgrab organization, http://farmlandgrab.org/

${ }^{9}$ LDPI, http://www.iss.nl/research/networks_and_projects/land_deal_politics_ldpi/

${ }^{10}$ ICAS,http://www.iss.nl/research/networks_and_projects/critical_agrarian_studies_icas/

${ }^{11}$ PLAAS, http://www.plaas.org.za/
} 
498 make an investigation on the consequences but also they should intentionally ask the third parties

499 to make such investigations continuously. Accordingly, the monitoring system should formally

500 be mentioned in the contract as an imperative article of the regulations.

501 It should be emphasised that not in every poor country, AO can be practiced, because it can 502 easily end to a "red" status. Therefore, we need a series of risk assessment studies on the bases of 503 both "country-case" and "crop-case". Such assessments should comprehensively address the 504 "political", "governance", "socio-economic", and "environmental" aspects of land deals. Given 505 the long duration of land deal contracts, such assessments should be regarded incessantly both 506 beforehand and when running the project while phasing out might never be the case.

507

508 Acknowledgement

509 The corresponding author is a beneficiary of a mobility grant from the Belgian Federal Science 510 Policy Office co-funded by the Marie Curie Actions from the European Commission. 
512

513

514

515

516

517

518

519

520

521

522

523

524

525

526

527

528

529

530

531

532

533

534

\section{References}

Ackello-Ogutu, C., 2011. Managing food security implications of food price shocks in Africa. Journal of African Economies 20(1), 100-141.

Afripol, 2010. Following China-US and India plan food security in Africa. http://www.afripol.org/afripol/item/184-following-china-us-and-india-plan-food-securityin-africa.html, Accessed October 2011.

AliAbdalla, A., 2009. Sudanese Chinese partnership in agriculture. http://www.sudantribune.com/Sudanese-Chinese-partnership-in,31862,

Accessed November 2011.

Amanor, K.S., 2012. Global resource grabs, agribusiness concentration and the smallholder: two West African case studies, Journal of Peasant Studies. 39(3-4), 731-749

Azadi, H., Schoonbeek, S., Mahmoudi, H., Derudder, B., De Maeyer, P., Witlox, F., 2011 a. Organic agriculture and sustainable food production system: Main potentials. Agriculture, Ecosystems \& Environment, 144, 92- 94.

Azadi, H., Talsma, N., Ho, P., Zarafshani, K., 2011b. GM crops in Ethiopia: a realistic way to increase agricultural performance? Trends in Biotechnology 29(1), 6-8.

Azadi, H., Verheijke, G.,Witlox, F., 2011c. Pollute first, clean up later? Global and Planetary Change 78, 77-82.

Azadi, H., Ho, P., Hasfiati, L., 2011d. Agricultural land conversion drivers: A comparison between less developed, developing and developed countries. Land Degradation and Development 22, 596-604.

Bazuin, S., Azadi, H., Witlox, F. 2011. Application of GM crops in Sub-Saharan Africa: Lessons learned from Green Revolution. Biotechnology Advances 29, 908-912. 
535 536

537 538

539

540

541 Cotula, L., 2011. Land grabs in Africa: is there an alternative?

Behrman, J., Meinzen-Dick, R., Quisumbing, A., 2011. The gender implications of large-scale land deals. IFPRI Discussion Paper 01056.

Cobo, L.G., Canales, F., Jiajie, L., 2011. Can Latin America feed China? http://www.latinbusinesschronicle.com/app/article.aspx?id=5221, Accessed March 2012.

Cotula, L., 2012. The international political economy of the global land rush: A critical appraisal of trends, scale, geography and drivers, Journal of Peasant Studies. 39(3-4), 649-680. http://www.iied.org/blogs/\%E2\%80\%98land-grabs\%E2\%80\%99-africa-there-alternative, Accessed March 2012.

Cotula, L., Vermeulen, S., Leonard, R., Keeley, J., 2009. Land grab or development opportunity? Agricultural investment and international land deals in Africa. www.ifad.org/pub/land/land_grab.pdf, Accessed November 2011.

Clover, J., Eriksen, S., 2009. The effects of land tenure change on sustainability: human security and environmental change in southern African savannas. Environmental Science \& Policy $12,53-70$.

Coughenour, C.M., Chamala, S., 2000. Conservation tillage and cropping innovation. Iowa State University Press.

Daniel, S., 2012. Situating private equity capital in the land grab debate. Journal of Peasant Studies. 39(3-4): 703-729.

Davies, M.J., 2009. The China monitor, issue 43. http://www.ccs.org.za, Accessed October 2011.

DEXIA, 2010. Food scarcity-trends, challenges, solutions. sri.dexia-am.com/.../news/201006/FOOD_SCARCITY_11_05.pdf,_Accessed March 2012.

Ewing, R., 2009. China slow to invest in expensive LatAm farmland. http://www.guardian.co.uk/business/feedarticle/8657479, Accessed March 2012. 
Ezra, Z., 2010. The new way of bio-colonialism in Ethiopia. www.anyuakmedia.com/Ethionews_temp_10_1_24.html, Accessed March 2012.

561 Fairhead, J., Leach, M., Scoones, I., 2012. Green grabbing: a new appropriation of nature?, Journal of Peasant Studies. 39(2), 237-261.

FAO, 2009a. On horizon 2050-billions needed for agriculture: high-level forum to weigh investment needs. http://www.fao.org/news/story/en/item/36107/icode, Accessed March 2012.

566

FAO, 2009b. Land acquisitions in Africa pose risks for poor. http://www.fao.org/news/story/en/item/19974/icode/, Accessed January 2012.

FAO, 2004. Land tenure systems and their impacts on food security and sustainable development in Africa. www.uneca.org/eca_resources/.../sdd/land_tenure_systems.pdf,_Accessed

571 FAO, 2002. Land tenure and rural development. Land Tenure Studies 3, Rome.

572 FIAN, 2012. Land grabbing in Kenya and Mozambique. http://www.fian.org, Accessed, $573 \quad$ Accessed March 2012.

574 Friis, C., Reenberg, A., 2010. Land grab in Africa: Emerging land system drivers in a 575 teleconnected world. http://www.globallandproject.org, Accessed December 2011.

576 Gerlach, A.C., Liu, P., 2010. Resource-seeking foreign direct investment in African agriculture. FAO Commodity and trade policy research working paper No. 31.

578 Globalvoices, 2011. Ethiopia: Are land grab deals a path to food security? 579 http://globalvoicesonline.org/2011/05/18/ethiopia-are-land-grab-deals-a-path-to-foodsecurity/, Accessed March 2012.

581 Grain, 2009. CGIAR joins global farmland grab. http://www.grain.org/article/entries/192-cgiar582 joins-global-farmland-grab, Accessed October 2011. 
583 584

585

586

587

588

589

590

591

592

593

594

595

596

597

598

599

600

601

602

603

604

Grau, R.H., Aide, M., 2008. Globalization and land-use transitions in Latin America. Ecology and Society. 13(2), 16.Grebmer, K.V., Fritschel, H., Nestorova, B., Olofinbiyi, T., PandyaLorch, R., Yohannes, Y., 2008. The Challenge of Hunger. http://www.ifpri.org, Accessed March 2012.

Grindle, M.S., 2002. Good enough governance: poverty reduction and reform in developing countries. www.gsdrc.org/docs/open/HD32.pdf, Accessed March 2012.

Hallam, D., 2009. Foreign investment in developing country agriculture-issues, policy implications and international response. http://www.oecd.org/dataoecd/30/39/44231828.pdf. Accessed November 2012.

Hall, R., 2011. Land grabbing in Southern Africa: the many faces of the investor rush. Review of African Political Economy 38(128), 193-214.

Haralambous, S., Liversage, H., Romano, M. 2009. The growing demand for land risks and opportunities for smallholder farmers. Discussion paper prepared for the Round Table organized during the Thirty-second session of IFAD's Governing Council. www.ifad.org/events/gc/32/roundtables/2.pdf, Accessed January 2012.

Hartwich, F., 2009. When food markets do not provide enough food. InfoResources Focus No $1 / 039$.

Hobbelink, H., 2011. Time to recall the land grabbers. http://www.commondreams.org/view/2011/12/06-0, Accessed March 2012.

Hong, K., 2011. Analysis of Daewoo land deal in Madagascar. http://www.slideshare.net/KevinHong3/analysis-of-daewoo-land-deal-in-madagascarpaper, Accessed March 2012. 
605

606

607

608

609

610

611

612

613

614

615 Madebo,

E.,

2011.

The December 2011.

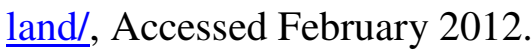

China's new rice bowl. http://www.jamestown.org/single/?no_cache=1\&tx_ttnews[tt_news]=35042, Accessed

Kersting, E., 2011. Dealing with the race for agricultural land. http://www.economicinsights.eu/2011/10/landgrabbing-foreign-investments-agriculturalhttp://www.gambelatoday.com/_blog/Opinion_and_Analysis/post/The_Impact_of_Land_G $\underline{\mathrm{rab} /}$, Accessed January 2012.

618 Maskus, K.E., 2004. Encouraging international technology transfer. 619 http://www.iprsonline.org/unctadictsd/docs/CS_Maskus.pdf, Accessed March 2012.

620 Meentzen, $\quad$ K., 2010. Resisting land grabbing in Ecuador. http://www.culturalsurvival.org/ourpublications/csq/article/resisting-land-grabbingecuador, Accessed October 2011.

623 Mehta, L., Veldwisch, G.J., Franco, J., 2012. Water Grabbing? Focus on the (Re)appropriation of 624 Finite Water Resources. Water Alternatives 5(2), 193-207.

625 Mihretie, K., 2010. Ethiopia on the verge of colony of many. www.farmlandgrab.org/10754, 626 Accessed March 2012.

627 Montenegro,

M., 2009. Hungry for Land. 
629 Mutangadura, G., 2007. The incidence of land tenure insecurity in Southern Africa: policy 630 implications for sustainable development. Natural Resources Forum 31, 176-187.

631 Namibian, 2012. Rush on African land.

632 http://www.namibian.com.na/index.php?id=28\&tx_ttnews[tt_news]=57579\&no_cache=1,

$633 \quad$ Accessed March 2012.

634 Nayak, P., 2004. Poverty and environmental degradation in rural India: a nexus. Annual 635 conference of NEEA held at Dibrugarh, Assam.

636 Oxfam, 2010. What is land grabbing and why should we care? 637 http://blogs.oxfam.org/en/blog/10-10-18-what-land-grabbing-and-why-should-we-care, $638 \quad$ Accessed March 2012.

639 Oxfam, 2009. Commercial pressures on land: Rethinking policies and practice for development. 640 www.commercialpressuresonland.org/wp-content/.../final-call.pdf, Accessed March 2012.

641 Pearce, F., 2011. Can 'climate-smart' agriculture help both Africa and the planet? 642 http://e360.yale.edu/feature/after_durban_can_climate_smart_farming_help_africa_and_th e_planet/2477/ Accessed September 2012.

644 Quan, J., 2006. Land access in the 21st century: Issues, trends, linkages and policy options. 645 ftp://ftp.fao.org/docrep/fao/009/ah245e/ah245e00.pdf, Accessed October 2011.

646 Robertson, B., Pinstrup-Andersen, P., 2010. Global land acquisition: neo-colonialism or 647 development opportunity? Food Security. 2(3), 271-283.

648 Rota, A., 2009. Livestock and land. http://www.ifad.org/lrkm/factsheet/land.pdf, Accessed $649 \quad$ March 2012.

650 Rowden, R., 2011. India's role in the new global farmland grab. 651 http://www.macroscan.org/anl/aug11/pdf/Rick_Rowden.pdf, Accessed March 2012. 
652 Rubinstein, C., 2009. Speaking freely: China's eye on African agriculture. 653 www.atimes.com/atimes/China_Business/KJ02Cb01.html, Accessed January 2012.

654 Rudi, L.M., Azadi, H., Witlox, F., 2012. Reconcilability of socio-economic development and 655 656 environmental conservation in Sub-Saharan Africa. Global and Planetary Change 86-87, 1-

657 Safransky, S., Wolford, W., 2011. Contemporary land grabs and their alternatives in the 658 659 Americas. International Conference on Global Land Grabbing, University of Sussex, April 6-8, 2011.

660

Saturnino, M., Borras, Jr., Jennifer, C.F., Kay, C., Spoor, M., 2011. Land grabbing in Latin 661 America and the Caribbean viewed from broader international perspectives. FAO.

662 663 664 665 666 667 668 669 670

Saturnino, M., Borras, Jr., Franco, J., 2010. Towards a broader view of the politics of global land grab: Rethinking land issues, reframing resistance. ICAS Working Paper Series No. 001.

Simo J.A.M., 2011. Land grabbing, governance and social peace-building issues in Cameroon: Case study of the roles of elites in land deals and commoditisation in the North West Region, International Conference on Global Land Grabbing 6-8 April 2011.

Simon, R., 2009. Fatal clashes erupt in Peru at roadblock. http://www.nytimes.com/2009/06/06/world/americas/06peru.html, Accessed, March 2012.

Skinner, J., Cotula, L., 2011. Are land deals driving 'water grabs'? Briefing: The global land rush. London: International Institute for Environment and Development (IIED). http://pubs.iied.org/17102IIED, accessed May 2012.

Smaller, C., Mann, H., 2009. A thirst for distant lands: Foreign investment in agricultural land and water. International Institute for Sustainable Development (IISD).

Smith, $\quad$ B., 2010. Golf and the great Lao land grab. www.atimes.com/atimes/Southeast_Asia/LA21Ae01.html, Accessed March 2012. 
676 Smith, D., 2009. The food rush: Rising demand in China and west sparks African land grab. 677 www.guardian.co.uk/environment/2009/jul/03/africa-land-grab, Accessed March 2012.

678 Songwe, V., Deininger, K., 2009. Foreign investment in agricultural production: Opportunities 679 and challenges. http://www.landcoalition.org/publications/foreign-investment-agricultural680 production, Accessed March 2012.

681 Spieldoch, A., Murphy, S., 2009. Agricultural land acquisitions: implications for food security 682 and poverty alleviation. http://www.wilsoncenter.org/topics/pubs/ASIA_090629_Land\%20Grab_rpt.pdf,_Accessed 684 October 2011.

685

STWR, 2012. Land grabbing the end of sustainable agriculture. http://www.stwr.org/foodsecurity-agriculture/land-grabbing-the-end-of-sustainable-agriculture.html,

Accessed March 2012.

TopManda, 2009. Food crisis and the global land grab, Varun-Madagascar contract. 689 http://farmlandgrab.org/2849, Accessed March 2012.

Toulmin, C., 2008a. Securing land and property rights in sub-Saharan Africa: the role of local institutions. http://www.pubs.iied.org/pdfs/G00460.pdf, Accessed March 2012.

692 Toulmin, C., 2008b. Securing land and property rights in Sub-Saharan Africa: The role of local institutions. Land Use Policy. 26, 10-19.

UGPulse, 2007. China offers 30Million US dollars to Uganda. http://www.ugpulse.com/ugandanews/government/china-offers-30million-us-dollars-to-uganda/4313.aspx, Accessed March 2012.

697 Ullenberg, A., 2009. Foreign direct investment (FDI) and land in Madagascar. Global Business 698 Review. Federal Ministry for Economic Cooperation and Development (GTZ). Eschborn, 699 Germany. doi: 10.1177/097215090000100201. 
700 701

702

706

707

708

709

710

711

712

713

714

715

716

717

718

719

720

721

UN, 2009. The world investment report: transnational corporations, agricultural production and development. http://www.unctad.org/en/docs/wir2009_en.pdf, Accessed March 2012.

UN, 2007. Indegenous people in http://www.un.org/esa/socdev/unpfii/.../6_session_tebtebba_iwgia.pdf, Accessed March 2012.

Von Braun, J., Meinzen-Dick, R., 2009. Land grabbing by foreign investors in developing $\begin{array}{llll}\text { countries: } & \text { risks } & \text { and }\end{array}$ http://www.ifpri.org/sites/default/files/publications/bp013all.pdf, Accessed March 2012.

White, J., White, B., 2012. Gendered experiences of dispossession: oil palm expansion in a Dayak Hibun community in West Kalimantan, Journal of Peasant Studies. 39(3-4): 9951016

Woodhouse, P. 2012. New investment, old challenges. Land deals and the water constraint in African agriculture. Journal of Peasant Studies. 39(3-4), 777-794.

Woodhouse, P., Ganho, A.S., 2011. Is water the hidden agenda of agricultural land acquisition in sub-Saharan Africa? International Conference on Global Land Grabbing, Institute of Development Studies and Future Agricultures Consortium, University of Sussex, UK, 6-8 April 2011.

Wünsche, N., 2011. Global Hunger Index 2011: Taming price spikes and excessive food price volatility.

http://www.rural-

development.de/fileadmin/download/archive/2011/5/rural_2011_5_Box.pdf, Accessed March 2012. 


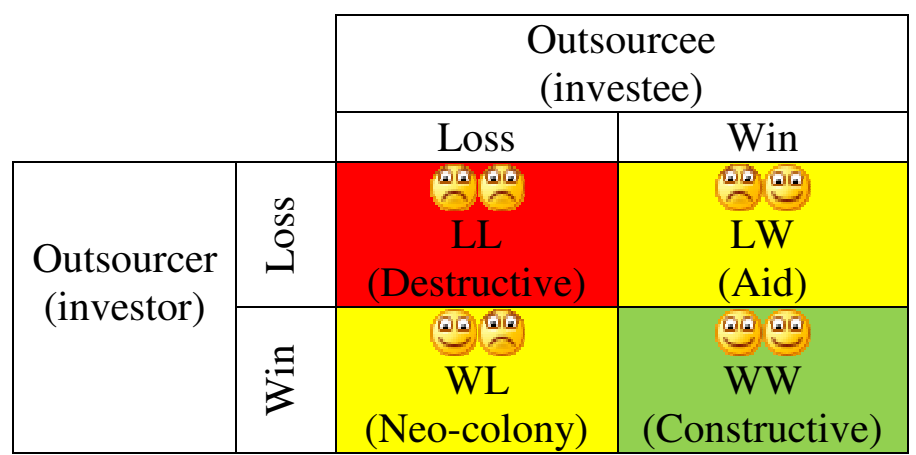

723 Fig. 1. Different possibilities of Agricultural Outsourcing: i) Loss-Loss (destructive); ii) Loss-Win (aid); iii) Win724 Loss (neo-colonialism); iv) Win-Win (constructive). 